\title{
ORIGINAL ARTICLE Customer Loyalty Scale in Sports Centers (Clssport)
}

\author{
DURSUN KATKAT ${ }^{1}$ \\ ${ }^{1}$ Mersin University \\ Corresponding to Dr. Dursun Katkat, E-mail: dkatkat@hotmail.com; Cell: +905322822915
}

\begin{abstract}
Background: Which was developed to determine the behaviors of loyalty, its sub-dimensions and their levels in people who receive services from the sports industry, will provide guidance to managers of sports centers for service provision, while increasing the awareness of the customers to shape their demands.

Aim: The aim of the study is to develop a scale to determine the customer loyalty levels of customers receiving service from sports centers serving in the public or private sector.

Methods: The research was designed as an original study in the general screening model.

Results: $\mathrm{KMO}=0.784$ and Barlett test $\mathrm{X}_{2}=6235,211(\mathrm{p}<.001)$ were conducted to test the suitability of the data for factor analysis. It was determined that the item factor loads of the scale ranged between 0.35 and 0.82 . As a result of the exploratory factor analysis, a structure with 40 items and three factors that explained $67.12 \%$ of the total variance was obtained. It was concluded that the correlation values $(.191-.311)$ between the sub-dimensions were appropriate, and the fit indices of the scale were significant $\left(X^{2}=726,66 \mathrm{sd}=408, p=.00, X^{2} / \mathrm{sd}=1.78\right)$.

Conclusion: In the light of the analyses made and the findings obtained, it was concluded that the CLSSC is a valid and reliable scale that can determine the level of customer loyalty among receiving service from sports centers.

Keywords: sports industry, sports marketing, customer loyalty, sports center, scale
\end{abstract}

\section{INTRODUCTION}

Customer loyalty refers to customers who are devoted and loyal to a firm. In other words, the concept of customer loyalty can be defined as the tendency to choose only one firm to receive services from and to continue this relationship for a long time. The concept of customer loyalty is the customization of the customer and customer value based on the marketing mix (4). From another approach, customer loyalty is the combination of customer value, customer cost, customer availability and customer communication (17).

Continuous change processes in the markets have increased the importance of retaining existing customers for businesses as well as acquiring new customers. Valuing the customer, reflecting this on the customer and establishing long-lasting customer relations have become a necessity for institutions and organizations. For example, Uyar emphasized in his publication in 2018 that businesses have to spend 5 times more energy, time and money in order to retain their lost customers. On the other hand, these businesses fail to regain $68 \%$ of the customers they lose (26). A $10 \%$ increase in customer retention can increase the valuation of a business by approximately $30 \%$ (1).

Considering that customer loyalty depends on the concept of satisfaction, the importance of the quality of the service provided is highly evident (12). The most important factors affecting customer loyalty are quality, image and the value attributed to the customer. For example, brand image is an important factor that determines consumers' perspectives on products they have not tried before and prevents them from turning to alternative products (11). Therefore, the natural result of customer satisfaction will be customer loyalty (7). A consumer who is happy with the product and service he/she purchases tends to prefer the same company later. This is the first step in customer loyalty (14). Although there are many factors that can alter customer attitude, re-choosing the service or products previously purchased and loyalty to the business will create customer loyalty (15).

However, businesses have to provide customers with at least 12 positive experiences in order to repair any negative experience that customers may go through and to ensure customer satisfaction again (27). While the probability of repeat sale to loyal customers is $60-70 \%$, their probability of selling to a new customer is around $15 \%$ (28). Therefore, as in every business, the concept of customer loyalty is critical in retaining the number of customers, gaining sales and cost advantages, and increasing turnover-profitability for sports centers as well. In order for sports centers to gain the loyalty of the customers they serve; they need to focus on the attitudes of their customers towards their business. In this context, customer loyalty can be examined in three approaches (9).

Behavioral approach consists of rational criteria such as the frequency and likelihood of the customer to choose the same service again (23). In this approach, the change in the benefit obtained by the customer from the service received the emergence of alternatives or the loss of the attractiveness of the service can change customer preference and the level of customer loyalty $(2,5)$.

Emotional approach includes the emotional dependence of the customer. It is the situation where the customer gives a positive opinion and refers the business to others even if he/she does not receive any service. This attitude shows that the customer is still a loyal customer (2).

Mixed approach evaluates both behavioral and emotional aspects of customer loyalty together (2).

As a result of customer loyalty, which is evaluated by behavioral, emotional and mixed approach, the sense of loyalty that customers will feel towards the business from which they purchase sports services emerges at four different levels. These are:

Unloyalty is signalized when a customer does not feel loyal to the products and services of a business and does not prefer the products and services of the business (18). 
False loyalty is shown when a customer buys a product or service from the business but does not have a positive view of that business (18).

Secret loyalty is expressed when a customer has positive thoughts about a business although he/she does not always prefer the goods and services of that business (3).

Strong loyalty is depicted when a customer is a permanent customer of a business and has a positive attitude towards its goods and services (6).

Significance Of the Study: The concept of customer loyalty is an important criterion in the sports industry as well. Customer (members) satisfaction, customer value, and the number and loyalty of customers are important factors that cannot be ignored by organizations providing sports services in the private or public sector. As a matter of fact, these factors are important both in terms of meeting the needs of the public to do sports and providing the financial support that the sports industry needs. Therefore, determining customer loyalty levels in sports centers has become a necessity in order to reach rational data about the customers who direct the inputs and outputs of sports facilities. This need will be met with the scale created as a result of the present study.

\section{MATERIAL AND METHOD}

In line with the information obtained from the literature review, the research question was designed within the framework of the concept of customer loyalty and its subdimensions, and an item pool of 51 items was designed to create a scale that can determine the level of "customer loyalty" in sports centers. In addition to many studies in the literature on scale development, the approach in the present study was based on Kim et al. Later, the design was shaped according to the opinions and suggestions received from 5 academicians who were experts in this field and the pilot application was started. Since the population of the research consists of customers receiving services from sports centers serving in the public and private sectors, the people participating in the pilot application were also selected from the same population.

A two-stage pilot study was conducted on the scale questions, and some expressions and sentence structures were edited. The scale consisting of 53 items was applied on a group of 40 people. The research group created for the pilot study consists of adults who exercise and do sports in sports centers in the private and public sectors. Subjects were asked to identify themselves with an alias on the scales they filled. After 14 days, the 53-item scale was applied again to the same group with the same aliases. The aliases were used to protect anonymity and to compare their perspectives on the scales. The statements and sentence structures were corrected by examining the data obtained from the first and second stages of the pilot study and making comparisons. In addition, by examining the Cronbach's Alpha values of the items, 13 items that did not meet the criteria were removed from the item pool, and the scale was given its final form with 40 items.

Scale Design: The scale consists of 40 items and three sub-dimensions. The sub-dimensions of the concept of customer loyalty in the literature were examined and three sub-dimensions were designed under the concept of customer loyalty in sports centers. Factor analysis was limited to these three dimensions.

- Rational dimension (price, hygiene, quality etc.)

- Emotional dimension (emotional attachment)

- Mixed dimension (both)

The scale is a 5-point Likert type scale and is interpreted based on total scores. 11 items $(9,16,18,25,56,27,31,32,35,36,38)$ in the scale are scored in reverse. The total score that can be obtained from the scale is between $40-200$. There is a linear relationship between total scale score and customer loyalty. In other words, the higher the total scores, the higher the level of customer loyalty. The scale can be applied to any adult, as well as parents on behalf of their children.

The scale was applied to a sample group of at least 5 times the number of items in the scale. Validity of the scale was examined by exploratory and confirmatory factor analyses. Exploratory and confirmatory factor analysis was examined with a sample group of 200 people, 113 men and 87 women. The sample group consisted of adult individuals (age: 18-57) receiving service from public and private sports centers.

Analysis of Data: Exploratory factor analysis (EFA), itemtotal correlations, confirmatory factor analysis (CFA), and reliability (Cronbach Alpha and split-half reliability) analyses were used in this study, which was conducted to develop a scale to determine customer loyalty levels of consumers receiving services from sports centers. It was determined that there were no missing values and incorrect data entries in the data set, and exploratory factor analysis (EFA) was performed to determine under which factors the expressions in the item pool would be collected. In addition, "item-total correlations" were calculated for the analysis of item distinctiveness. Confirmatory factor analysis (CFA) was performed in order to verify the three-factor structure determined by exploratory factor analysis (EFA) and the results are presented below.

\section{RESULTS}

Findings of Exploratory Factor Analysis (EFA): In the exploratory factor analysis, "maximum likelihood technique" and the "promax rotation method" were used and the variance explained by each sub-dimension was required to be at least $5 \%$. The eigenvalues were taken as $\geq 1.00$ and the item factor loads were taken as $\geq 0.30$. Furthermore, a difference of $\geq 0.10$ was required among the items with a sufficient factor load collected under more than one factor $(21,22)$.

In order to test the suitability of the data collected from the sample group for factor analysis, $\mathrm{KMO}$ and Bartlett tests were conducted. $\mathrm{KMO}$ was found to be 0.784 and Barlett test $x 2$ value was found to be 6235,211 ( $p<.001)$. The fact that $\mathrm{KMO}$ is higher than .60 and a significant Barlett test result indicates that the data is suitable for factor analysis $(19,20)$. The results of the exploratory factor analysis for the scale are presented in Table-1. 
Table-1 Item Factor Loads of the Scale, Variances Explained by the Subscales, and Item Analyses

\begin{tabular}{|c|c|c|c|c|}
\hline Articles & Factor 1 & Factor 2 & Factor 3 & $\begin{array}{l}\text { Total Item } \\
\text { Correlation }\end{array}$ \\
\hline M1: This facility is always very clean. & .82 & & & .44 \\
\hline M2: I prefer this facility because the cost of service is affordable. & .78 & & & .49 \\
\hline M4: I think this facility is more practical than any other facility. & .75 & & & .48 \\
\hline M5: I prefer this facility because the service is always high quality. & .72 & & & .49 \\
\hline M6: I prefer this facility because of the accessibility. & .69 & & & .51 \\
\hline M8: I can get my money's worth at this facility. & .65 & & & .50 \\
\hline M13: This facility is my first choice, I haven't tried any other facilities yet. & .61 & & & .51 \\
\hline M14: I prefer the facility because of the good WC and shower bath opportunities. & .58 & & & .52 \\
\hline M16: I don't like it when the facility is crowded. & .55 & & & .53 \\
\hline M26: I can make a change if there is an alternative with lower prices. & .54 & & & .51 \\
\hline $\begin{array}{l}\text { M27: I can make a change if there is an alternative facility providing a higher } \\
\text { quality of service. }\end{array}$ & .50 & & & .47 \\
\hline M38: Customers are valued only for their money at this facility. & .49 & & & .45 \\
\hline M9: I won't choose this facility again for the next time. & & .66 & & .52 \\
\hline M10: I have the opportunity to socialize with other people in this facility. & & .64 & & .43 \\
\hline $\begin{array}{l}\text { M11: Even if I experience minor issues in this facility, I will continue to get } \\
\text { services. }\end{array}$ & & .61 & & .44 \\
\hline M20: I think people in this facility are pleased with the services. & & .59 & & .45 \\
\hline M21: I'm a loyal customer, and I'll always prefer this facility. & & .62 & & .50 \\
\hline M23: Even if I don't get very good service from this facility, my opinion is positive. & & .58 & & .51 \\
\hline $\begin{array}{l}\text { M24: If I choose another facility, I would think I'm a disgrace to the employees at } \\
\text { this facility. }\end{array}$ & & .55 & & .39 \\
\hline M31: I don't feel like I belong to this facility. & & .52 & & .43 \\
\hline M32: I don't feel comfortable in this facility. & & .50 & & .46 \\
\hline M34: I trust the employees of this facility. & & .49 & & .59 \\
\hline M35: Customer relations of employees are poor. & & .47 & & .52 \\
\hline M36: Facility managers don't care about customers. & & .45 & & .37 \\
\hline $\begin{array}{l}\text { M37: The facility gives SPECIAL AND DIFFERENTIAL treatment to its former } \\
\text { customers/participants. }\end{array}$ & & .44 & & .38 \\
\hline M40: I am a long-standing customer in this facility. & & .43 & & .36 \\
\hline M3: I prefer this facility because it's always clean. & & & .55 & .45 \\
\hline M7: I prefer this facility because the coaches and trainers in there are qualified. & & & .52 & .49 \\
\hline M12: I'm generally satisfied with this facility. & & & .50 & .48 \\
\hline M15: I've been a customer of this facility for a long time. & & & .49 & .39 \\
\hline M17: I think the customer profile of this facility is good. & & & .45 & .42 \\
\hline M18: I think there is a need for facilities that can provide better service. & & & .44 & .44 \\
\hline M19: I can continue to get services from this facility again for some other times. & & & .43 & .42 \\
\hline M22: I think there is no need to try other facilities. & & & .42 & .45 \\
\hline $\begin{array}{l}\text { M25: If there's a better alternative, I can change the facility that I have chosen } \\
\text { already. }\end{array}$ & & & .41 & .39 \\
\hline M28: Under no circumstances would I decide to go to another facility. & & & .40 & .38 \\
\hline M29: I would recommend this facility to other people. & & & .38 & .39 \\
\hline M30: I feel like "I am the owner" in this facility. & & & .37 & .39 \\
\hline M33: I spend most of my sports-related time at this facility. & & & .36 & .41 \\
\hline \multirow[t]{3}{*}{ M39: This facility cares about "customer satisfaction". } & & & .35 & .43 \\
\hline & $\% 48,19$ & $\% 10.07$ & $\% 8,86$ & \\
\hline & \multicolumn{3}{|c|}{ Total Variance $=\% 67,12$} & \\
\hline
\end{tabular}

As a result of the exploratory factor analysis, a three-factor structure that explains $67.12 \%$ of the total variance was obtained. As seen in Table 1, the first factor consists of 12 items and the total variance explained by the first factor is $48.19 \%$, the second factor consists of 14 items and the total variance explained by the second factor is $10.07 \%$, and the third factor consists of 14 items and the total variance explained by the third factor is $8.86 \%$. The first factor (items: 1,2 , $4,5,6,8,13,14,16,26,27,38)$ was named as the "rational customer loyalty" sub-dimension, the second factor (items: $9,10,11,20,23,24,31,32,34,35,36,37,40)$ was named as the "emotional customer loyalty" sub-dimension, and the third factor (items: $3,7,12,15,17,18,19,22,25,28,29,30,33,39)$ was named as the "mixed customer loyalty" sub-dimension.

It was determined that the item factor loads of the scale ranged between 0.82 and 0.35 . According to Tabachnick and Fidell (25), the factor load of the scale should be at least 0.32 . Therefore, according to the data obtained, it was concluded that the item factor loads of the three-factor structure were sufficient. On the other hand, Kline (12) states that the variance explained by the scale should be at least $40 \%$. In the present study, the total variance explained by the scale was found to be $67.12 \%$. Therefore, it was concluded that the results were sufficient to decide on the factor structure.

Pearson correlation analysis was conducted to determine the relationship between sub-dimensions of the scale. The correlations between the sub-dimensions varied between .191 and .311, and it was concluded that the sub-dimensions were different from each other. 
Table-2 Correlations between the Sub-Dimensions of the Scale

\begin{tabular}{|l|l|l|l|}
\hline & 1 & 2 & 3 \\
\hline Factor 1 & 1 & & \\
\hline Factor 2 & $.204^{*}$ & 1 & \\
\hline Factor 3 & $.191^{*}$ & $.311^{*}$ & 1 \\
\hline
\end{tabular}

${ }^{*} \mathrm{p}<0.05$ (2-tailed)

In addition, it is recommended that the correlation coefficient between factors, which is defined as multicollinearity, should not exceed .90 (24). When Table-2 is examined, it is seen that the correlation coefficients between the subdimensions are below 0.90 and there is no problem of multicollinearity between the sub-dimensions of the scale (22).

Findings of Confirmatory Factor Analysis (CFA): Confirmatory factor analysis was conducted to examine the model fit of the three-factor structure obtained as a result of the Explanatory Factor Analysis. In the confirmatory factor analysis, GFI, CFI, NFI, RFI, IFI and AGFI multiple fit indices were used and the acceptable fit value for each index was considered as 0.90 . In addition, 0.08 fit value was accepted as the criterion for the basic fit indices RMSEA, RMR and SRMR $(20,21)$.

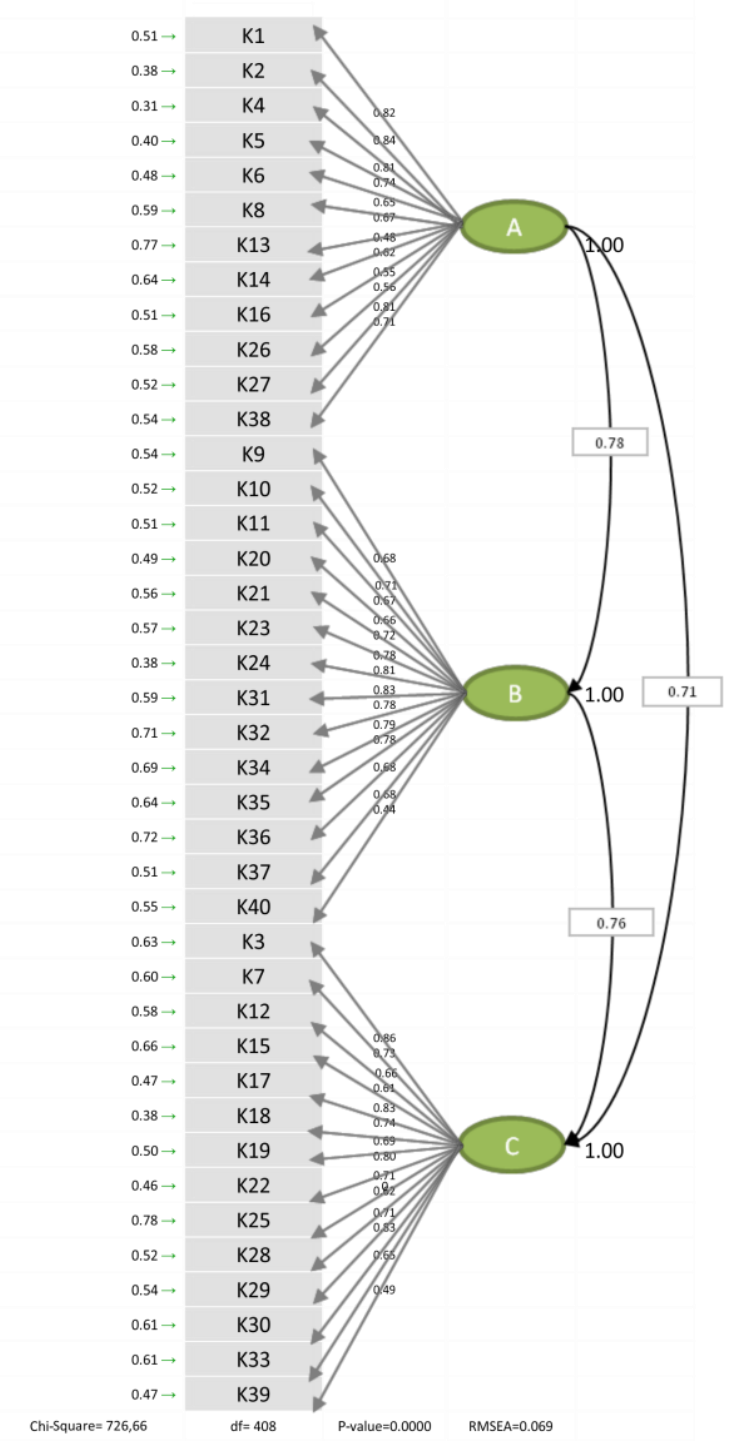

Figure-1 CFA Results for the Scale
When Figure-1 is examined, it is seen that the fit indexes of the Customer Loyalty Scale in Sports Centers, which consists of 40 items and three sub-dimensions, are all significant $\left(X^{2}=726,66 \mathrm{sd}=408, p=.00, X^{2} / s d=1.78\right)$. The fit indices were found as RMSEA $=.070, \mathrm{RMR}=.055, \mathrm{NFI}=$ $.95, \mathrm{NNFI}=.95, \mathrm{CFI}=.94, \mathrm{IFI}=.94, \mathrm{RFI}=.94, \mathrm{AGFI}=.90$, and $\mathrm{GFI}=.91$. The model fit indices of the three-factor structure tested with the CFA analysis were found to be sufficient and the three-factor structure of the scale was confirmed.

After the standard analysis, the $t$ values between the factors and items were examined, and it was concluded that there were no items incompatible with the overall scale. Jöreskog and Sörbom (8) state that the absence of red arrows about $t$ values indicates that all items are significant at the .05 level. The absences of red arrows in the $t$ values were evaluated as all items were significant at the .05 level and were consistent with the overall scale.

The results obtained from the exploratory and confirmatory factor analyses demonstrate the construct validity of the scale. Then, internal consistency and split-half reliability analyses were performed to examine the reliability of the scale, and the findings are presented in Table-3.

Table-3 Reliability Coefficients of the Scale Calculated Using the Internal Consistency and Split-Half Reliability Method

\begin{tabular}{|l|l|l|}
\hline Dimensions & $\begin{array}{l}\text { Internal Consistency } \\
\text { Reliability }\end{array}$ & $\begin{array}{l}\text { Split Half } \\
\text { Reliability Test }\end{array}$ \\
\hline Factor 1 & .87 & .78 \\
\hline Factor 2 & .82 & .74 \\
\hline Factor 3 & .81 & .71 \\
\hline Total Scale & .86 & .77 \\
\hline
\end{tabular}

Landis and Koch (13), and Robinson et al. (16) state that having a reliability coefficient of .70 and above is sufficient for the scale to be considered reliable. Hence, when Table3 is examined, it is seen that the reliability analysis values for the "Customer Loyalty Scale in Sports Centers (CLSSC)" are above .70, and the reliability coefficient for the overall scale is .86. In other words, it was found that the sub-dimensions and items of the scale statistically met the reliability criteria.

\section{DISCUSSION AND CONCLUSION}

As a result of the present study, a valid and reliable measurement tool that can be used in field studies was developed in line with the findings obtained from the exploratory and confirmatory factor analyses and the findings from the reliability analysis. It was concluded that the "Customer Loyalty Scale in Sports Facilities (CLSSC)" is a valid and reliable scale that can measure the loyalty level of customers receiving services from sports centers. 
CLSSC can contribute to the field of sports sciences as a valid and reliable scale that can be applied by sports centers serving in the public and private sectors to their customers.

Having reviewed literature, various customer loyalty scales are found in different fields and subjects. Many valid and reliable scale studies on "customer loyalty" have been published, especially in the fields of management, business, and marketing. However, a customer loyalty study has not been carried out considering the management of sports centers. Therefore, this study is unique in terms of sports management, and it will also create awareness among businesses and customers creating supply and demand in sports centers. In this way, managers will have more information about what needs to be done to ensure and increase customer loyalty, and their awareness on this issue will also increase. On the other hand, customers will learn about the level of loyalty they feel towards a sports center they receive services from and the underlying reasons. These earnings, in return, will increase the service quality and the number of customers due to the intensity of the relationship between customer awareness and supply and demand. The result of the mentioned advantages will also be reflected in the public sector and opportunities for more people to receive physical education and do sports will expand.

\section{REFERENCES}

1. Bain Company (2017); Loyalty, https://www.bain.com/insights/topics/loyalty (12.11.2020).

2. Bowen, John T. \& Shiang-Lih Chen (2001); "The Relationship Between Customer Loyalty and Customer Satisfaction", International Journal of Contemporary Hospitality Management, v.13(5), p. 213-217.

3. Çatı K. \& Koçoğlu MC. (2008); "A Research to Determine the Relationship Between Customer Loyalty and Customer Satisfaction", Selçuk University Journal of Institute of Social Sciences, v.19, Konya/Turkey.

4. Grönroos, C., (1994); "From Marketing Mix to Relationship Marketing: Towards A Paradigm Shift in Marketing", Management Decision, v.32(2), p.4-20.

5. Hartmann P. \& Apaolaza I. (2006); "Managing Customer Loyalty in Liberalized Residential Energy Markets: The İmpact of Energy Branding", Energy Policy, www.elsevier.com/locate/enpol

6. IIrik Ö. (2005); "The Effects of Service Quality on Customer Loyalty and an Application in Tansaş Supermarket Operations", Master Thesis, Dumlupınar University Journal of Institute of Social Sciences, Kütahya/Turkey.

7. Jones T.S. \& Earl W.Jr. (1995); Why Satisfied Customers Defect, Harward Business Review, v.73(6), p.88-99.

8. Jöreskog K. G. \& Sorbom D. (1996); Lisrel 8.54 Reference Guide. Lincolnwood, IL: Scientific Software International.

9. Kim K., Jeong I., Park J., Park Y., Kim C., Kim T. (2007); "The Impact of Network Service Performance on Customer
Satisfaction and Loyalty", Expert Systems with Applications, Elsevier, v.32, p.822-831.

10. Kline R. B. (2011); An Easy Guide to Factor Analysis. New York: The Guilford Press

11. Koçoğlu C.M. (2009); The Effect of Service Quality on Customer Loyalty and Application in a Five Star Hotel, Master Thesis, Duzce University, Turkey.

12. Kotler P. (2000); Kotler and Marketing (translate: Ayse Özyagcılar), System Publishing, Istanbul.

13. Landis J.R. \& Koch G.G. (1977); "The measurement of Observer Agreement for Categorical Data”. Biometrics, v.33, p.159-174.

14. Martenson R. (2007); Corporate Brand Image, Satisfaction And Store Loyalty: A Study of The Store As A Brand, Store Brands and Manufacturer Brands, International Journal of Retail \& Distribution Management, v.35(7), p.544-555.

15. Oliver R.L. (1999); Whence Consumer Loyalty, Journal of Marketing, v.63, p.33-44.

16. Robinson J.P., Shaver P.R., Wrightsman L.S. (1991); Criteria for Scale Selection and Evaluation in Measure of Personality and Social Psychological Attitudes, California Academic Press. San Diego, USA.

17. Roman G.H. \& Scott W.C. (1997); The Successful Marketing Plan, NTC. Business Books, Illinois, USA.

18. Rowley J. \& Dawes J (1999); "Customer Loyalty: A Relative Concept for Libraries", Library Management, v.2(6), p.345351.

19. Rowley J. \& Dawes J. (2000); "Disloyalty: A Closer Look at Non-Loyals", Journal of Consumer Marketing, v.17(6), p.538547.

20. Seçer I. (2013); Data Analysis with SPPS and LISREL, Anı Press, Ankara/Turkey.

21. Seçer I. (2015); Psychological Test Development and Adaptation Process: SPSS and LISREL, Anı Press, Ankara/Turkey.

22. Shevlin M.E. \& Lewis C.A. (1999); The revise, social anxiety scale: exploratory and confirmatory factor analysis. The Journal of Social Psychology, v.2, p.250-252.

23. Srinivasan S.S., Anderson R., Ponnavolu K. (2002); "Customer Loyalty in e-Commerce: an Exploration of its Antecedents and Consequences", Journal of Retailing, v.78(1), p.41-50.

24. Pallant J. (2005); SPSS Survival manual: A Step-by-Step Guide to Data Analysis Using SPSS for Windows. Australian Copyright, Australia.

25. Tabachnick B.G. \& Fidell L.S. (2001); Using multivariate statistics. Needham Heights, Allyn and Bacon, MA/USA

26. Uyar A. (2018); Customer Relations and the Future. Efil Publishing, Ankara/Turkey.

27. Uyar A. (2019); Examining the Relationship Between Customer Satisfaction and Customer Loyalty with Structural Equation Model: An Application on Automobile Users, Electronic Journal of Social Sciences, ISSN:1304-0278, v.18(69), p.41-57.

28. Yokuş E. (2016); Surprising Statistics of Sales. Chapter 4: Customer Retention and Requesting References, https://www.linkedin.com/ (22.11.2020). 